\title{
A GYÓGYPEDAGÓGIA KÉT MEGHATÁROZÓ MÁRIÁJA: MARIA MONTESSORI ÉS HÁRI MÁRIA
}

\author{
Szerzők: \\ Oravecz Adrienn \\ Eszterházy Károly Egyetem
}

Lektorok:

Estefánné Varga Magdolna

Eszterházy Károly Egyetem

Feketéné Szabó Éva

Pető András Főiskola

Mező Katalin

Debrceni Egyetem

Szerző e-mail címe:

ora_adri@msn.com
Nemes Magdolna

Debreceni Egyetem

Oravecz Adrienn (2016): A gyógypedagógia két meghatározó Mátiája: Maria Montessori és Hári Mária. Különleges Bánásmód, II. évf. 2016/4. szám, 35-47. DOI 10.18458/KB.2016.4.35

\begin{abstract}
Absztrakt
Jelen írás a gyógypedagógia történetének két kiemelkedö személyiségét Dr. Montessori Máriát és Dr. Hári Máriát mutatja be. Dr. Montessori Olaszország elsö orvosnője volt, késöbb végzett pedagógiai tanulmányokat. Dr. Hári Mária fiatal orvostanhallgatóként Dr. Petö András mellett tevékenykedett, aki megteremtette a konduktív nevelés alapjait. A hivatásukon túl további hasonlóság közöttük, hogy munkásságuknak köszönhetöen mára mindkét módszer nemzetközi ismertségnek örvend. A két személyiségen keresztül bepillantást nyerünk pedagógiai rendszerükbe, a Montessori Módszerbe és a Pető Módszerbe. A téma azért releváns, mert mindkét fejlesztési eljárás lehetővé teszi a sérültek integrációját, hogy teljes értékü életet élhessenek.
\end{abstract}

Kulcsszavak: Dr. Montessori Mária, Dr. Hári Mária, Integráció, Inkluzió

Diszciplinák: Alternatívpedagógia, Gyógypedagógia, Konduktív pedagógia

\section{Abstract TWO DETERMINING MARIAS OF THE SPECIAL EDUCATION: MARIA MONTESSORI AND MÁRIA HÁRI}

This study presents the decisive pedagogy of two Marias: Dr. Montessori and Dr. Hári. Dr. Montessori was the first woman in Italy who received a medical degree and it was many years later when she did pedagogical studies as well. Dr. Hári was a young medical student when she started to work with Professor Petö who had laid down the basics of Conductive Education. Dr. Montessori and Dr. Hári had a lot in common: not just their profession was the same but thanks to their hard work both pedagogy became famous internationally. Through their personality the reader will have a glance into their educational methods as 
well. The topic is relevant because both educational system make it possible for people with disabilites to integrate into society and live a meaningful life.

Keywords: Maria Montessori dr., Mária Hári dr., Integration, Inclusion

Disciplines: Alternative Pedagogy, Special Needs Education, Conductive Education

\section{A vonatkozó szakirodalom bemutatása, értékelése}

Dr. Montessori Mária életmüvét B. Méhes, 1994-es és Kurucz, 1995-ös müvei mutatják be. Mind B. Méhes Vera mind Dr. Kurucz Rózsa sokat tett azért, hogy Montessori munkásságát megismertesse a hazai olvasóközönséggel. Például, B. Méhes Vera ellenőrizte szakmailag a magyar fordítást Montessori A gyermek felfedezése című müvéhez. Dr. Hári Mária életmüvét Balogh 2005-ös írása mutatja be először részletesen, ennek a münek a bővített képekkel és angol szöveggel is kiegészített változata Balogh és Horváth Dezsőné 2014-es munkája. A Montessori pedagógia óvodai alkalmazását tárgyalja Kiss és Szirt Miklósné 1992-es és B. Méhes 1995-ös müve. A konduktív pedagógia rendszerét Hári 1991-es müve ismerteti. Annak ellenére, hogy mind a Montessori, mind a Konduktív nevelést bematató müvek még a 90-es évek elején és közepén születtek tartalmuk máig releváns és megkerülhetetlen a téma alapos ismertetéséhez. Márkus 1994-es írása betekintést ad a súlyosan és halmozottan mozgásfogyatékos gyerekek számára készült képesség fejlesztő eszközökről. Bár a könyv elsődleges célcsoportja a mozgásukban korlátozottak, jó néhány eszköz a Montessori pedagógiában is megtalálható. Az írásbeli kommunikáció fejlesztését ismertetik a következő cikkek: Novák, 2000; Horváth Dezsőné és Feketéné Szabó, 2012; Pintér, 2013; Pintér és Gál, 2013. Horváth Dezsőné tudományos publikációi betekintést adnak a rajzkészség fejlesztésébe. A zenei neveléssel Komáromi 2006-os könyve foglakozik.

\section{Alkalmazott módszerek}

Tanulmányomban a szakirodalmi háttér segítségével végzek összehasonlító elemzést. Az összehasonlítás szempontsorát mutatja be az 1. táblázat. A szakirodalmi háttért megfigyelés teszi teljesebbé a Pető András Főiskola Óvodájában és a Gyermeksziget Montessori Óvodában.

1. táblázat: A Montessori és a Konduktív Pedagógia összehasonlításának szempontsora. Forrás: a Szerzö.
1. Életút
2. Sérülés megközelítése
3. Nevelési elvek és nevelö szerepe
4. Tanulási környezet
5. Képességfejlesztés és eszközök

\section{Maria Montessori életútja}

1870-ben született Olaszország Chiaravalle településén. Középiskolai tanulmányait egy müszaki középiskolában végezte, ahova csak fiúk jártak. Egyetemi tanulmányait a müegyetemen kezdte meg, de egy év elteltével átiratkozott az orvosi karra. Az orvosi diploma megszerzése után két évig a pszichiátrián tanársegédként dolgozott. Az itt látottak 
nagyhatással voltak rá, rájött, hogy a fogyatékosságot nem elég csupán a medicina felöl megközelíteni. 1898-as tanügyi kongresszuson ismertette forradalmian újnak számító gondolatait melynek hatására Romában létrehozták a gyenge tehetségü gyermekek iskoláját. A pedagógiai koncepciójának kidolgozásában segítségére voltak Seguin és Itard munkái. 1907-ben létre jött az első Gyermekek Háza Romában.

1909-ben először Olaszországban tart tanfolyamot, majd 1913-től kezdve a világ számos országában is, képezte az érdeklődő pedagógusokat. Az első Montessori Intézet Svájcban nyitotta meg kapuit, a következő New Yorkban létesült. 1929-ben Dániában megalakult a montessori pedagógia nemzetközi szövetsége. Hazánkban 1932-ben alakult meg a Magyar Montessori Egyesület. A spanyol polgárháború miatt Hollandiában talált menedékre, így ezt követően Amszterdam lett a mozgalom centruma. 1946-ig tartózkodott Indiában a háború miatt. A háború végeztével visszatér Hollandiába ahol halála előtt nem sokkal az amszterdami díszdoktorává nevezték ki. 1952-ben hunyt el.

\section{Hári Mária életútja}

1923-ban született Budapesten. Orvostanhallgatóként is már Pető mellett segédkezett, majd Pető halálát követően az Intézet vezetője lett. Sok nyelven beszélt, így alapos tájékozottsággal rendelkezett az orvosi és egyéb külföldi szaklapokban. Az Egyesült Királyságban, 1968-ban a Spastic Society felkérésére átütő sikerü előadást tartott, amellyel ismertté vált a módszer külföldön is. 1987-ben hivatalos megállapodás született arról, hogy a Pető Intézet segít kiépíteni a konduktív pedagógia hálózatát az Egyesült Királyságban. A módszer felkeltette Lady Diana érdeklődését, aki 1992-ben látogatást tett az intézetben és Hári Doktornőt a Brit Birodalom rendjével tüntette ki.

Igazgatása alatt konduktor-tanító szak indult, hazai, és külföldi hallgatók számára. Beindította az Országos szaktanácsadói hálózat kiépülését. A konduktív pedagógia alapmüvei mind az Ö tollából születtek. 2001-ben hunyt el.

\section{Hasonlóságok a két Mária életútja között}

A keresztnevükön túl azonos bennük a hivatásuk. Mindketten a szívükön viselték a fogyatékos gyerekek rehabilitációjának és társadalmi integrációjának ügyét. Úgy gondolták, hogy a medicina eszközei nem elegendőek, ezeknek a gyerekeknek sokkal inkább megfelelö nevelésre van szükségük ahhoz, hogy a fogyatékosságuk ellenére teljes életet élhessenek. „Hiába való minden iskolai reform, módszer, erkölcsnevelés, ha éppen azokra nincs hatásuk, akikre a társadalom védelme szempontjából legjobban kellene hatást gyakorolni. Olyan módszert kell alkalmazni, amely azoknak a gyerekeknek a fejlődését is elősegítené, akik valamilyen fogyatékosságban szenvednek." (Kurucz, 1995. 9. o.). Tudásukkal előbb saját hazájuk gyógypedagógiai gyakorlatát és szakirodalmát gazdagították, majd külföldön is ismertté tették nevelési koncepciójukat. Montessori 1913-tól kezdve tartott külföldön tanfolyamokat, míg a konduktív nevelésben mérföldkőnek számított a birminghami egyetemen 1987-ben indult konduktorképzés. Nemcsak tudásuk átadását tartották fontosnak a következő generációk számára, hanem szorgalmazták a Konduktív és Montessori pedagógia szellemében müködő köznevelési hálózat létrehozását is. Az első Gyermekek Háza Romában nyílt meg. Budapesten a Kútvölgyi úti épületében müködik Pető András Főiskola az óvodája, az általános iskola a Villányi úton található. Szakmai szervezetek létrehozásában is tevékenyen részt vettek. 1929-ben Dániában megalakult a Montessori pedagógia nemzetközi szövetsége. A konduktív pedagógia első jelentős nemzetközi szervezete az 1991-ben alakult 
Nemzetközi Pető András Társaság. A legújabb 2004-es alapítású az Európai Konduktív Egyesület, tagjai az Európai országokban müködő nemzeti egyesületek. Munkásságukat számos elismeréssel jutalmazták.

\section{A fogyatékosság megközelítése}

Hasonlóság a két alternatív pedagógiában, hogy bár mind Montessori mind Hári orvosi végzettséggel rendelkezett túllépve a medicina hatáskörét úgy vélték, hogy, sokkal, nagyobb hatékonysággal tudnak segíteni a sérült gyerekeken, ha pedagógia eszköztárát hívják segítségül. Montessorira nagy hatással volt a svájci Itard és a francia Séguin. Az ő eszközeiket és metodikai eljárásukat tanulmányozta és gondolta tovább. Annyira sikeres volt a fejlesztés, hogy a legtöbb szellemileg akadályozott neveltje végül az épekkel együtt tudott vizsgázni. Petö is hasonlóan gondolkodott, amikor kidolgozta a konduktív nevelést. A nevelés hangsúlyozása a fontos, mert hitt abban, hogy a sérülés ellenére az idegrendszer rendelkezik tartalékokkal és a sérült agyterületek funkcióit átveszik, az épek. Az új idegi kapcsolatok kiépítését optimális tanulási környezet megteremtésével lehet elösegíteni. A konduktív nevelésben elsődleges cél a megfelelő müködés szakszóval az ortofunkció kialakítása. Az ortofunkció eléréséhez az alapvető emberi tulajdonságokat mozgósítják, ilyenek a tanulás és az önálló cselekvésre való képesség vágya (Hári,1991.).

\section{Nevelési elvek és a nevelő szerepe}

Mind a Montessori mind a Pető Módszerben az egyik legfontosabb nevelési elv a lét a humánum tisztelete. Minden ember értékes teremtmény. Az emberre jellegzetes tulajdonságok még a központi idegrendszer sérülése vagy szellemi akadályozottság esetén is jelen vannak. Az ember kreatív. Saját maga és környezete képét felépíti magában. Amit felépít az nem puszta másolat, hanem új konstrukció, amely némileg eltérhet attól, amit megtanult, de mindig összefüggő egész az ember tudatában. A következő azonos nevelési elv a tolerancia elve. A másság az emberi lét természetes formája. Minden ember más és más, így a másság gazdagítja az emberi nemet. A pedagógiai optimizmus jellemzi mindkét módszert. A nevelhetőségbe vetett hitt. A neveléssel még a súlyos szellemi akadályozottság és központi idegrendszeri károsodás esetén is meg van a fejlődés lehetősége. A nevelés valódi értékét az emberben létre jött pozitív változások képviselik, ,a jót kell kihozni az emberekből” (Hári, 1997. 15. o.).

A következő azonosság a tevékenység-centrikusság. A játék, a tanulás, és közösségi programok együttes megvalósulást jelenti. A nevelés akkor a legeredményesebb, ha tanuló aktív bevonásával elősegíti a szükebb és tágabb környezetének felfedezését. A környezet megismerésének folyamatában fontos a másokhoz való alkalmazkodás, amely segíti önmaguk jobb megismerését. A környezet visszajelzései fontosak, mert általuk fejlödik a gyermek önértékelése. Montessori ezt a következőképpen fogalmazta meg:" Alapfeladat olyan környezet létrehozása, amely a gyermeket minél több örömet nyújtó, életkoruknak megfelelö és egyben képességeiket fejlesztő tevékenységre motiválja." (B. Méhes, 1994. 11. o.). A konduktív pedagógiában cselekvésnek számít az érdeklődés, a célképzés és tervezés is.

Jellemző a totalitás, teljesség elve a megfelelö környezet nem elegendő szükséges a nevelö hatása is, aki alaposan megfigyeli a gyermeket és ennek megfelelően rendezi be a környezetet, hogy a gyermek kibontakoztathassa képességeit. A megfigyelésnek a konduktori munkában nagyon fontos szerepe van, hiszen az un. első vizsgálat során a konduktor operatív 
megfigyelést végez, felméri a diszfunkciós személy állapotát, tudakozódik a korábbi beavatkozásokról, kijelöli a további fejlesztési célokat. A megfigyelés mellett még egyéb diagnosztikai eljárásokat is alkalmaz úgymint faktoranalízis, és rajzvizsgálat. (Hári,1991).

Az integráció elve a fizikai, szellemi, akarati és jellembeli fejlődés egységének a megvalósulást jelenti. Mind a Montessori mind a Pető-féle pedagógiát a komplex fejlesztés igénye jellemzi. A következö lényeges nevelési elv a közösségi nevelés. A közösségi nevelés csoportos formában történik. Biztosítja a szociális facilitációt, erősíti a csoport tudatot és az összetartozás érzését. A csoportos foglakoztatás azért előnyős a fogyatékosok számára, mert segít elkerülni a szegregációt, sőt előkészíti későbbi óvodai és iskolai közösségekbe való integrálásukat. Montessori a heterogén csoportok híve volt, mert úgy vélte, hogy a kisebb gyerekek szívesebben tanulnak a nagyobbaktól. A konduktív pedagógiában az életkori összetétel alapján homogének a csoportok, de a diagnózis szempontjából a heterogenitás jellemző, mert azonos tünet együttes esetén is jelentős egyéni eltérések vannak. Természetesen a nevelési elvek precíz gyakorlati megvalósításához jól képzett szakembere van szükség. Az új emberközpontú, önállóságra nevelö pedagógia más pedagógust kíván. Montessori erről a következőket mondja: „Új müvészetet kell megtanulnia azt, hogy a gyermek segítőtársa és vezetője legyen, és elvezesse őt azokhoz az eszközökhöz, amelyekre akkori fejlődése fokán szüksége van" (B. Méhes, 1994. 18. o.). Az idézetben Montessori azt fogalmazza meg, hogy a pedagógus ne a tanuló helyett akarjon cselekedni, hanem csak egy minimális segítséget nyújtson, amellyel a gyermek már képes lesz önállóan elvégezni a feladatát. A konduktív pedagógiában szintén meg van ez a nevelői szemlélet. „, A kondukció a nevelőnek egy olyan funkciója, amely feltételezi a gyermek helyzetébe való beleélést oly módon, hogy saját magából annyit ad hozzá a gyermek megoldásához, hogy azzal hozzájáruljon a helyes koordináció kialakításához.” (Balogh és Horváth Dezsőné, 2014. 28. o.) Mindkét pedagógiában a tanító rávezeti a tanulót arra, hogyan tudja önerejéből kivitelezni az adott tevékenységet.

Nagyon hasonló személyiségvonásokkal írják le a pedagógust. Montessori így jellemzi: „Környezetünk ösztönzői nem csak a tárgyak, hanem azok az emberek is, akikkel nemcsak érzékeinkre ható kapcsolatunk van. Ahhoz, hogy élni tudjunk az is kell, hogy szeressenek minket." (Kiss és Szirt Miklósné, 1992. 23. o.). Hári a konduktor személyiségét katalizátorként írja le. Fontos, hogy szórakoztató, tréfás és humoros és dinamikus legyen. A konduktor pozitív személyiségével ösztönzi a gyermeket. A bensőséges nevelö-nevelt kapcsolat kialakítása még sokkal fontosabb, mint a napi közoktatásban, hiszen a rá kell vennie a sérült gyermeket, hogy feszegesse a saját határait, hogy a lehető legtöbbet hozza ki magából, ami csak maximális bizalommal érhető el.

\section{Tanulási környezet}

Montessori idejében még egyáltalán nem volt általános a gyermek méreteihez igazított környezet. Felhívta a figyelmet, hogy nem egészséges egész nap görnyedten ülni az iskolapadban, mert az kóros elváltozásokat okoz. Montessori a gyermek mozgásigényét tartotta szem előtt, így könnyü és kisméretü bútorokkal rendezte be óvodáit. Montessorinál a praktikum mellett ugyanolyan hangsúlyos volt az esztétikum és a rendezettség. „Vannak különböző tárgyak, amelyek a különböző életkorú gyermekekhez beszélnek, szinte megszólítják őket. Ilyenek a fények, a színek, a vidám és díszes tárgyak, hangok, amely a gyermek figyelmét magukra vonják és cselekvésre késztetik” (Montessori, 2002. 84. o.). A konduktív pedagógiában szintén nagyon hívogató a tanulási környezet. 


\section{Képességfejlesztés és fejlesztőeszközök}

Mind a Montessori mind a Konduktív nevelésben a mozgáson keresztül történik a fejlesztés, „a gyermek testi nevelését szorosan összekapcsoljuk a gyakorlati élettel: a mozgásfejlesztés épüljön be a gyermek komplex személyiségének nevelésébe." (Montessori, 2002. 80. o.). Montessorinál a mozgás és koordináció fejlesztésére szolgál, az un. csendlecke, vagy csendjáték. A csendlecke során a gyerekek halk aláfestő zene kíséretében végeznek a szőnyegen gyakorlatot, ahol arra kell ügyelniük, hogy lábfejüket mindig a kijelölt vonalra helyezzék. A feladat nehezített változata, ha vízzel teli pohárral kell végig járni a vonalat.

A konduktív pedagógiában a mozgásfejlesztés adja a konduktív komplex program alapját, amely gondosan strukturált és az egyén napirendjének szerves része. A mozgás indítás alapja az un. ritmikus intendálás. A ritmikus intendálást Balogh és Kozma így definiálja: „A feladatok végrehajtásakor a résztvevők egyes szám első személyben hangosan kimondott szándéka. A cselekvés terve mit és hogyan fognak csinálni, azaz az intenciójuk verbalizálása, majd a szándékuk szerinti cselekvés végre hajtása az erre szánt időtartam alatt, amelyet számolással, dallal, verssel jeleznek (Balogh és Kozma, 2009. 14. o.). A többi fejlesztési terület (memória, figyelem, látási és hallási jelenlét, tér és időbeli orientáció) a mozgásos alapprogram, minden egyes feladatában megvalósul így képezve egy komplex egészet.

További kiemelt fejlesztési területek mindkét pedagógiai koncepcióban a ritmusérzék, a rajz, az íráskészségének fejlesztése. Montessorinál a zenei nevelés hallásfejlesztő játékokkal kezdődik. A harangsor egy olyan eszköz, amely 26 fatalpra erősített kis harang a „c” skálának a hangjaiból és egy ütőpálcából áll. A feladatok során meg kell különböztetni egymástól a hallott hangokat, vagy épp hangmagasság szerinti sorrendbe kell állítani. Nagyon alkalmasnak tartja a népdalokat és népi dalos játékokat. A konduktív pedagógia szintén a magyar népdalkincsböl merít, és ezek segítségével fejleszti a gyerekek ritmusérzékét. A központi idegrendszeri sérülés következtében gyakran alakul ki légzési probléma, illetve a beszélőszervek érintettsége miatt különböző mértékü artikulációs nehézség. A zenei nevelés során ugyanazokat a területeket fejlesztik, mint az egészséges gyerekek óvodai nevelésében. A legfontosabb az ének-zene tanításának megkezdéséhez a helyes levegővétel elsajátítatása. Például, ping-pong labda fújása az asztalon, vagy a gyerekek elsorolják egymás nevét egy levegővétellel (Komáromi Lajosné, 2006.). Ha a helyes légzéstechnikát sikerült elsajátítani jöhet az első főterület a ritmus érzék fejlesztése. A ritmusérzék fejlesztésén belül fontos az egyenletes lüktetés megéreztetése. Ezután következik a dal és mondóka ritmusának megtanítása. Tapsolás, dobolás, kopogás az adott ritmus ütemére. A zenei hallásfejlesztés során a hangmagasság és dinamikai érzék fejlesztése történik. Az hallás fejlesztés jótékonyan hat a belső hallásra is. Például, dúdolhatnak egy képről.

A következő fontos terület a rajzkészség fejlesztése. Montessori pályája kezdetén csak a rajzsablonok használatát gondolta jónak, mert a sokszor lerajzolt sablon által a gyerekek elsajátítják a pontos és határozott vonalvezetést, ami fontos előkészítő fázisa az írás tanulásnak. A színezés technikája segíti az írószer könnyed kezelésének megtanulását. A színérzékelést fejlesztő eszköze egy ötször két darabból álló tábla, amely piros, kék, fehér, zöld és sárga színekből áll. A feladat során a gyerekeknek ki kell választani az azonos színúeket és megnevezni azokat. A színárnyalatok megkülönböztetésére is dolgozott ki egy eszközt. Egy kilencrekeszü dobozban nyolc színnek hét különbözö árnyalata található a legvilágosabbtól a legsötétebbig. Egy kör alakú lapra sugárformában kell elhelyezni a színtáblákat a sötét, felöl haladva a világos árnyalat felé. 
A mozgássérült gyereknél az agykéreg organikus károsodása következtében szétesik a szenzomotoros koordináció. Ami a vizuomotoros koordináció zavaraival jár, nehézségek tapasztalhatók a Gestallt-látásban, valamint a percepcióban (Horváth Dezsőné, 1999). A percepció zavar megnyilvánulhat abban, hogy a testvázát nem ismeri és ezért nem képes megmutatni a testrészeit. Téveszti az irányokat, síkban nem jól tájékozódik. Gyakori a látótér kiesés, ami nem minden színre sokszor csak bizonyos színekre vonatkozik. Közeli-távoli, álló vagy mozgó tárgyat nem tud fixálni. Zavar jelentkezik a tér és mélység érzékelésében. Összehasonlító rajzvizsgálat során kiderült, hogy az emberfigura elemei hamarabb alakulnak ki az egészséges gyerekeknél, viszont a sérült gyermekek több magyarázatot füztek rajzaikhoz.

A mozgássérült gyermekcsoport firkatevékenységét tünet specifikusan is elemezte Horváth Dezsőné. Az athetosis-os gyerekek rajztevékenységére jellemző a kezdőpont megtalálásának nehézsége és fixálás képtelensége. A ceruzát görcsösen fogják, vagy nem szokványos módon. Mivel jellemző tünet a nehézkes, akadozó beszéd rajztevékenységüket nem kommentálják, ellenben élénk képzelőerőről tanúskodnak vibráló és színekben gazdag alkotásaik. Tetraparesis spasztika esetén a merev izomtónus miatt görcsös a ceruzafogás, nehéz a megfelelő nyomaték megtalálása a forma és a mérettartás szintén. A vonalvezetés nagyon egyeletlen, egyszer túl erős, máskor túl gyenge. A diplégiások ábrázolótevékenysége ugyan életkorúknak megfelelö, de rossz a vizuális emlékezetük és a vizuális ritmuskövetésük. Az ataxiások esetében gyakori a tremor, azaz akaratlan remegés, ami miatt pontatlan a vonalvezetés. Jellemző a változó írásnyomaték, a figyelmük nehezen leköthető és gyorsan lankadó. A hemiplégiásoknál a végtagok hiányos ábrázolása jelent meg a rajzon, illetve a ritmikus sor alkotásának képtelensége (Horváth Dezsőné, 2000).

2016.05.29.-én alkalmam volt megfigyelni egy óvodai rajzfoglalkozást a Pető András Főiskolán a Kisvakond csoportban. A teljes létszám 14 fö, de aznap két gyermek hiányzott. A csoporttagoknak tetraparalizis spasztikája van, ami azt jelenti, hogy mind a négy végtagban fokozott az izomtónus müködése, ezért a rajzolást az asztalnál dalra és mondókára végzett kar és ujj lazítógyakorlatok előzték meg. Először nyújtott karemelést végeztek, mindkét karral egyszerre, majd váltva. Majd váltva érintették meg a jobb és bal karukat, miközben verbálisan kísérték a cselekvést. A kezükben babzsákot tartva gördítő mozdulatokat végeztek a térdükön. Ezután szivacslabda segítségével nyitották és zárták az ujjukat, majd megismételték a feladatot szivacslabda nélkül. A ráhangoló és lazító gyakorlatsor végén jött a napi feladat: cseresznyefa festése. A csoportra festőkötényt adtak, hogy ne legyenek maszatosak minden asztalra csúszásgátlót helyeztek, és jól fixálható rajztáblákat. A fa törzsét a gyerekeknek előre megfestette az óvónő, így nekik csak a gyümölcsökkel teli lombkoronát kellett megalkotni. A festési technikákat egyénre szabták. Volt aki, ecsettel, volt, aki szivacsot mártogatva festett. Volt olyan gyerek is aki, a radíros végü ceruzát mártva készítette el müvét. A gyerekek láthatóan nagyon élvezték a feladatot, és végül nagyon szép cseresznyefák születtek.

Az írás tanításának fontos előkészítő fázisa a rajzolás és festés, ami fejleszti a vizuomotoros koordinációt és a téri orientációt. A rajzkészség fejlesztése után mindkét pedagógiában a grafomotorosfejlesztés következik. Montessori szembefordult az általános pedagógiai gyakorlattal, hogy hét éves kor előtt nem ajánlatos megismertetni a gyerekeket a betükkel, mert még nem képesek az absztrakt gondolkodásra és a kezük sem elég ügyes az íráshoz. Gyakorlati munkája során sikerült bebizonyítania, hogy a gyerekek látványként fogják fel a betüt, és ugyanúgy lerajzolják, mint a cicát ábrázoló képet. Eszköztárában található egy nyolcszor nyolc cm-es kartonlap, amelyre rózsaszínnel a magánhangzók kékkel 
a mássalhangzók vannak felragasztva. A gyermek elöbb ujjával végig tapintja a betü formáját, miközben kimondja a betühöz tartozó hangot, így társítva össze a látványt és a hangot.

A konduktív nevelés legtöbb alanyának a központi idegrendszeri sérülés következtében dominancia zavarja, van, itt nem a dominancia kialakítása az elsődleges szempont, az a lényeges, hogy a gyermek szimmetrikusan terhelje a felső végtagjait. A Pető Módszer az agy két féltekének szimmetrikus összehangolására törekszik, minden feladatba ágyazott mozgássor ezt a célt szolgálja, amelyet laterális áthangolásnak neveznek (Feketéné Szabó és Horváth Dezsőné, 2012). A 2. táblázat szemlélteti a grafomotorosfejlesztés kivitelezését a konduktív pedagógiában, majd ezt követi egy ilyen típusú egyéni foglakozás leírása.

\section{2. táblázat: A grafomotorosfejlesztés felépítése}

\begin{tabular}{|l|l|l|}
\hline \multicolumn{1}{|c|}{ Célok } & \multicolumn{1}{|c|}{ Feladatok } & \multicolumn{1}{c|}{ Szakaszai } \\
\hline $\begin{array}{l}\text { Írás és vonalvezetés } \\
\text { technikai kivitelezésének } \\
\text { megvalósítása a } \\
\text { fokozatosság elve alapján. }\end{array}$ & $\begin{array}{l}\text { Grafikai ábrázolás esztétikai és } \\
\text { pszichológiai hatásának érvényre jutatása } \\
\text { vagyis, hogy a tevékenységet kedvvel } \\
\text { végezzék. }\end{array}$ & $\begin{array}{l}\text { Manipuláció (asztalnál végzett ülö/ } \\
\text { pálcával a levegőben végzett } \\
\text { gyakorlatok ülő helyzetben/tépés/ } \\
\text { ragasztás) }\end{array}$ \\
\hline Vizuo-motoros fejlesztés. & Tériorientáció tanulása. & Íráselemek elökészítése \\
\hline $\begin{array}{l}\text { Kézmozgás és } \\
\text { finommotorika fejlesztése. }\end{array}$ & Alak-háttér differenciálás tanulása. & $\begin{array}{l}\text { Eszközfogás differenciált egyénre } \\
\text { szabott ceruzahasználat }\end{array}$ \\
\hline $\begin{array}{l}\text { Szem és kézfej } \\
\text { koordinációjának a } \\
\text { fejlesztése. }\end{array}$ & $\begin{array}{l}\text { Vizuális figyelem fejlesztése.(Vizuális } \\
\text { differenciálás/diszkrimináció) }\end{array}$ & $\begin{array}{l}\text { Lateralitás- Kezesség } \\
\text { Satírozási technikák } \\
\text { Alaklátás és formaálandóság } \\
\text { fejlesztése. } \\
\text { Vonalközben való tájékozódás. } \\
\text { Vonalelemek ábrázolása. }\end{array}$ \\
\hline
\end{tabular}

2016.06.03.-án megtekintettem egy egyéni óvodás íráskészség fejlesztőfoglalkozást, amely most párosan zajlott. A pedagógus elmondta, hogy azért rakta a kislányt és kisfiút párba, mert a kislány motiválja a kisfiút. A foglalkozás a helyes ülöhelyzet felvételével kezdődött. Ezután a gyerekek bemutatkoztak nekem. Le kellett dobolniuk hány évesek.

Az évszakkorongon be kellett állítaniuk a megfelelő évszakot. Majd Zsófi baba gurította nekik a labdát miközben be kellett fejezniük helyesen a mondatot. Ezután vízhang játék következett, helyes sorrendbe vissza kellett ismételniük a szavakat, majd meg kellett nevezni a hallott fogalmak gyüjtőnevét, ami a madarak volt. A következő feladatban arra az érzékszervükre kellett mutatniuk, amelyikkel látják vagy hallják a szót. Például, a fénykép szó kimondásakor mind a ketten ügyesen rámutattak a szemükre. A gyerekek madárcsalogatót játszottak, amely során a konduktor a kezükbe helyezet egy-egy madarat ábrázoló képet és a páros felváltva nevezte meg mit lát az ábrán. A következő feladat során a kezükből fecskefejet formáltak, ha a fecske szót hallották az énekben és a csőr szó hallatára pedig a dal ütemét követve nyitogatták és csukogatták a kezüket.

Ezután következett az óra fő célja a fecskevonal megtanulása. A fecskevonal tanulása egy színes pontozott táblán vette kezdetét, a gyerekeknek a pontozott vonalon végig haladva kellett elvezetniük madár lesre az erdészt. A táblán csak akkor léphettek előre, ha a sok féle madárnév között meghallották a fecske szót. A feladat végén annyit kellett tapsolniuk ahány fiókát láttak a fészekben. A kisfiúnak csak hangosan számolva sikerült a helyes számot letapsolnia. A konduktív pedagógia is alkalmazza a taktilis és látásingerek összekapcsolást, egy f betü formájú zsenilia fonalat kellett végig tapogatniuk az ujjacskájukkal. Nehezítésként, miután párszor megtapogatták, nekik kellett újraalkotni és végül a levegőbe megrajzolni a betüt. A betűelem képét kirakták mogyoróból. Majd sorközben tanulták leírni a betüképét, vastag filccel. Végül az óra zárásaként grízben 
rajzolták meg. Ezt láthatóan nagyon élvezték, ahogy az apró grízszemek csiklandozták az ujjaikat. Az írás tanulás vonalközben és grízben való gyakorlását ábrázolja az 1. és 2. kép.

\section{1. kép: A fecskevonal tanulása a vonalközben}

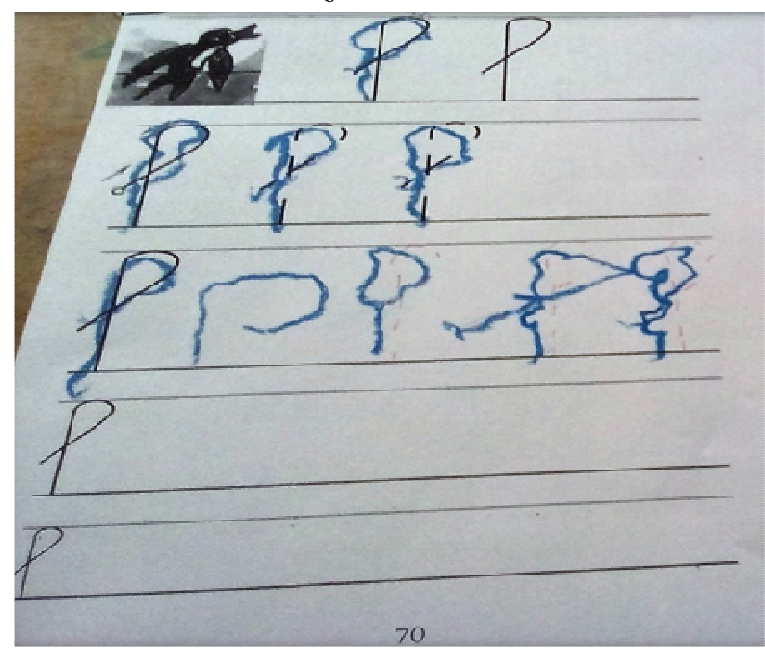

2. kép: Fecskevonal a grízben

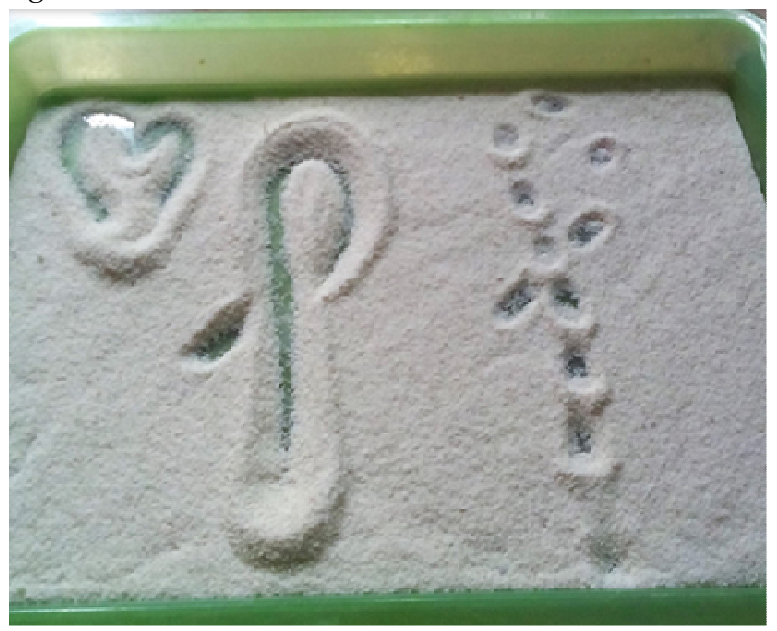

\section{Látogatás a Gyermeksziget Montessori Óvodában}

2016.10.13.-án látogatást tettem a Békásmegyeren található Gyermeksziget Montessori Óvodában. Az óvoda kellemes környezetben található tágas udvarral és barátságos belső térrel. Az óvoda jelenleg 6 vegyes életkorú csoporttal müködik. A csoport teljes létszáma 24 fö, de aznap négy kisgyermek hiányzott. Az óvodai program a beszélgető körrel indult. $\mathrm{Az}$ óvónő az aktuális napra és hónapra volt kíváncsi. Majd mindegyik gyereknek kiosztotta, hogy ő melyik nap és úgy kellett egymás után sorba rendeződniük, ahogy a hét napjai követik egymást. A kicsik ezt követően visszafele rendeződtek el, és így mondták el a hét napjait. A reggelihez is úgy mentek ki kezet mosni, hogy az óvónő megmondta melyik „nap” állhat ki a sorból. A ráhangoló beszélgető kör után a reggeli következett. A kisasztalokat a napos terítette meg és a reggeli végén ő is szedte le. A csoportszoba a gyermekek méretéhez volt igazítva. Ezt követően a gyerekek különféle játékokat szedtek le a polcokról. Voltak, akik színeztek, 
voltak, akik különféle állatokat raktak ki. A csoport fiú tagjait a színes fakockák bűvölték el és ezekből építettek különböző alakzatokat. A csoport ikerpárja egymással játszott és alkotta meg a színkört. Az idősebbek a számokkal és a betükkel ismerkedtek már. A pedagógus csak akkor avatkozott a gyerekek önálló játék tevékenységébe, ha látta, hogy valaki segítségre szorul, vagy ha egy-egy gyermek odahívta, hogy nézze meg mit alkotott. Ez az elmélyült játéktevékenység addig folytatódott, amíg a háttérben meg nem szólalt a csendkörre hívó zene. A csendkörben a gyerekek égő gyertyával a kezükben a vonalon lépkedve egyensúlyoztak, majd odafordultak a társukhoz, akinek át szerették volna adni a gyertyát.

Itt én elbúcsúztam a csoporttól, hogy tudjak még beszélgetni az óvodavezetőjével, Stefán Mariannal. A beszélgetés a személyes élettörténetre, valamint a Montessori Pedagógia filozófiai és gyakorlati kérdéseivel foglakozott. Szóesett az óvoda napi gyakorlatáról, a Montessori Egyesületről és annak céljairól, valamint a konduktív pedagógiáról. Az óvodavezető véleménye szerint a konduktív pedagógia nagyon jól beleilleszthető a montessori rendszerbe, hiszen mindkét pedagógia középpontjában a gyermeki önállóság elősegítése, a sajátos nevelésigényü gyermekek integrálása a legfontosabb cél.

\section{Összefoglalás}

Munkám a Montessori és a Konduktív Pedagógia, illetve jeles alakjaik összehasonlításáról szólt. Az összehasonlító elemzés először Maria Montessori és Hári Mária életét és munkásságát vetette össze egymással. A tanulmány további részében olyan elemekre fókuszáltunk, amelyek mindkét nevelési koncepcióban megtalálhatók, mint például a nevelö, akinek elsődleges feladata a gyermek önállóságra nevelése; a motiváló és tágas, de maximálisan gyermek szükségleteihez igazított tanulási környezet. Központi fogalom a gyermek képessé tevése az éneklésre, rajzolásra és az írásra, amely lehetővé teszi a normál közoktatásba való integrálásukat. A szociális tanulást és a másokhoz való alkalmazkodást a csoportos formában történő fejlesztés segíti elö.

\section{Irodalom}

B. Méhes Vera (1994): Montessori pedagógiai rendszere és alkalmazása az óvodában. Nemzeti Tankönyvkiadó, Budapest.

Balogh, M., Horváth Dezsőné (2014): Dr. Hári Mária (1923-2001.) Kiadja a Pető András Főiskola, Budapest.

Balogh E., Kozma I. (2009): A konduktív nevelés gyermekneurológiai indikációja. Ideggyógyászati Szemle 2009. 62.(1-2) sz. 12-22.

Feketéné Szabó, É., Horváth Dezsőné (2012): Én is tudok írni Gondolatok a grafomotoros fejlesztés lehetőségeiről a mozgássérültek konduktív nevelése során. Fejlesztö Pedagógia 2012. 23.(3) sz. 31-34.

Hári, M.(szerk.)(1991): A konduktív pedagógiai rendszer hatékony müködésének alapelvei és gyakorlata. Kiadja a Nemzetközi Pető Intézet, Budapest.

Háry, M. (1997): A konduktív pedagógia története. Kiadja a Mozgássérültek Pető András Nevelö-képzö és Nevelö Intézete, Budapest.

Horváth Dezsőné (1999): Gondolatok mozgássérült óvodáskorú gyermekek vizuális fejlesztéséröl. Fejlesztö Pedagógia 1999. 10.(4-5.) sz. 83-85. 
Horváth Dezsőné (2000): Mozgássérült óvodások firkatevékenységének megfigyelése. Magyar Pedagógia 2000. 101.(1.) sz. 47-62.

Kiss, E., Szirt Miklósné (1992): Montessori- Pedagógia az óvodában. Kiadja a Horizont2000 Humán Szolgáltató Bt.

Komáromi Lajosné (2006): A játék természetes örömével Ének-zenei nevelés óvodai gyakorlatomban. Antalógia Kiadó, Lakitelek.

Kurucz Rózsa (1995): Montessori-Pedagógia. Nodus Kiadó, Veszprém.

Montessori Mária (2002): A gyermek felfedezése. Cartaphilus Kiadó, Budapest. 


\section{Melléklet:}

Interjú Stefán Mariannal a Gyermeksziget Montessori Óvoda vezetőjével és a Magyar Montessori Egyesület elnökével.

Beszélgetőtársam Stefán Mariann, aki a Zipernovszky utcai Gyermeksziget Montessori Óvoda vezetője és a Magyar Montessori Társaság Elnöke.

- Kedves Mariann mesélne nekem arról, hogyan kezdödött a karrierje. Mióta dolgozik óvodapedagógusként?

- Óvodapedagógusként 1980. 09.01. óta dolgozom. Pályámat itt kezdtem ebben az intézményben, amely akkor még a Zipernovszky Óvoda néven működött, hat csoporttal, de magas gyermeklétszámmal, majd a 80-as évek közepétől csökkent 33-36 fösre a csoportok létszáma.

- Hogyan került kapcsolatba a Montessori Pedagógiával?

- A Montessori Pedagógiával a 80-as évek közepén ismerkedtem meg, B. Méhes Vera montessori pedagógus előadásai által. Nagyhatással voltak rám ezek az előadások, amelyek többek közt a pedagógiai megújulás lehetőségével és különféle reformpedagógiai irányzatokkal foglalkoztak. Majd 1989-ben részt vettem egy vezetői konferencián, ahol már nemcsak az elméleti részébe, hanem a módszertanába is betekintést nyerhettem B. Méhes Vera mentorálásával. Az óvoda müködésében is ebben az évben történt változás, mert addig a szocialista rendszer szemléletének megfelelően müködött és csak a rendszerváltozás után lehetett szabadon programot választani.

- Említette B. Méhes Verát, aki a magyarországi montessori mozgalom elindítója volt. Többek közt megalapítója és tiszteletbeli tagja volt a Magyar Montessori Egyesületnek is, amelynek jelenleg Ön az elnöke. Kérem, meséljen egy kicsit bövebben az egyesületről.

- Az egyesület 1992. május. 12.-én jött létre, amelynek alapítóülésén magam is részt vettem. A montessori tanfolyamot 1991-ben végeztem el és annyira megtetszett, hogy rögtön az ott tanultakat megpróbáltam átültetni a mindennapos pedagógiai gyakorlatomba. 1994-től jó magam bemutatós montessori pedagógusként működtem, de mivel nagyon elhívatott voltam az egyesület megválasztott az elnökének. A jelenlegi egyesület jogutódja a Magyar Montessori Egyesületnek, amelyet még Kenyeres Elemér és Veszely Ödön vezetett. A legfontosabb célja az egyesületnek, hogy a Montessori Pedagógia rendszerét megismertesse, elmélyítse és folytonosságát fenntartsa a hazai intézményekben, különös tekintettel az állami intézményekre, hogy minél több gyermek nevelésébe kerülhessen bele ez a pedagógiai módszer. Külföldön ez a módszer inkább a magán szférába honosodott meg. Célunk még továbbá hogy, folyamatosan tájékoztassuk a pedagógusokat a külföldi montessori szakmai megújulásokról. 2004 óta tagjai vagyunk az Európai Montessori Egyesületnek, évente veszünk részt konferenciákon, az idén Berlinbe volt és a felelősség kérdése volt a témája. 1992-óta van szaklapunk is, amely egészen B. Méhes Vera 2013-as haláláig évente két példányban jelent meg, azóta évente csak egy összevont számot tudunk kiadni. Ebben a lapban szakmai tájékoztatást adunk a filozófiáról és bemutatjuk az országban folyó gyakorlatot. Szakfordítások által szélesítjük kollegáink látókörét, hogy ne csak a hazai, de a külföldi gyakorlatban is alapos tájékozottsággal rendelkezzenek. A képzések megszervezése és lebonyolítása szintén az egyesület kiemelt feladatai közé tartozik. Van egy 80 órás és 80 kreditpontos alapképzésünk. A képzés tematikája és gyakorlati része teljesen megegyezik az európai montessori képzéssel. Az alapképzésre épül rá egy emelt szintü montessori tanfolyam is. Továbbá az ELTE szervezésében van egy két éves montessori szakpedagógus képzés is. A 
képzést első sorban pedagógusoknak és gyógypedagógusoknak ajánljuk, de a szülők részéről is egyre nagyobb érdeklődést tapasztalok.

- Az Ön véleménye, tapasztalata szerint miben adhat többet egy montessori óvoda a gyermek egészséges testi-lelki fejlödéséhez, mint egy hagyományos óvoda?

- A pedagógus példaadása nagyon fontos, mert mi nem direkt oktatjuk a gyermekeket, hanem megpróbáljuk ezt belső szükségletté tenni, itt a gyerekek szabadon tevékenykedhetnek, és mi támogatjuk őket ebben. Nagyon elfogadóak vagyunk. A vegyes életkorú csoportok is ezt segítik elő, hogy a nagyobbak támogassák a kisebbeket, és a fiatalabbak merjék elfogadni a segítséget idősebb társaiktól. A környezet szintén a felfedezésre sarkallja a gyerekeket, ha tevékenységben örömét leli az hosszú távon elönyösen hat az egyéni fejlődésére, így könnyebben mozgósíthatok azok a területek is amely, még nem olyan jól fejlettek.

- Az óvoda pedagógiai programjában kiemelt helyen szerepel a toleranciára való nevelés a másság elfogadása. Vannak-e jelenleg SNI-s és BTM-s gyermekeik? Vannak-e kifejezetten ezt elösegítö óvodai vagy óvodán kívüli programok, foglakozások?

- 2009-ben még csak egy speciális nevelésigényü növendékünk volt, de a számuk évröl évre nő, így jelenleg 10 ilyen gyermekünk van. Két szervi fogyatékos. Kifejezetten ilyen foglakozásunk nincs, hiszen a tolerancia a gyerekek napirendjébe szervesen beépül. A közös játékkal és az által, hogy fogyatékkal élö társuk is a csoport teljes értékü tagja. A csendjáték is az egymásra való odafigyelést és az egymás felé fordulást szolgálja, miközben ügyesedik a gyerekek mozgáskoordinációja a vonalon való egyensúlyozás által.

- Az eredeti eszköztárat alkalmazzák?

- Igen, de másféle fejlesztőeszközöket is használunk, mert szeretnénk a gyermekeinknek biztosítani a minél szélesebb körü megismerést és fejlődést. Közel 300 fejlesztő eszközünk van. Mindenből egy van, de ennek van több változata, mert ezzel is szeretnénk a gyerekek kompromisszum készségét és egymással való kommunikációját fejleszteni.

- Hogyan épül fel a gyerekek napirendje? A napirendben melyek a fö fejlesztési területek?

- A mozgásfejlesztés nagyon hangsúlyos része a gyerekek óvodai programjának. A testnevelés óra a Gergely Ildikó- féle program szerint zajlik. Idén lehetőségünk nyílt az önkormányzat által biztosított ingyenes úszásfoglalkozáson való részvételre. Az óvodán kívüli tevékenységek is a testmozgást és egészséges testkép kialakítását szolgálják. A lányok müvészi tornán, míg a fiúk foci és kosárlabda edzéseken vehetnek részt. Ezek a foglakozások jótékonyan befolyásolják a kognitív készségek fejlődését, elősegítve az írás, olvasás, számolás készségének kialakulását. Ezek az alapkészségek nélkülözhetetlenek a későbbi sikeres iskolai élethez. A napok fel vannak osztva aszerint, hogy aznap melyik a fö fejlesztési terület. Ma épp az érzékelés fejlesztése volt a napirenden.

- Milyen fejlesztöszakemberek segítik a sajátos nevelésigényü gyermekeket a mindennapok során, elösegítve felzárkóztatásukat ép társaikhoz?

- Befogadó intézmény vagyunk 2002 óta, így rendelkezünk a szükséges szakember gárdával is. Van saját pszichológusunk, logopédusunk és fejlesztőpedagógusunk. Utazó gyógypedagógus látja el az SNI-s gyermekeket. Pedagógiai asszisztens segíti a munkánkat.

- Ismeri-e a konduktív pedagógiát? Mi a véleménye mennyire egyeztethetö össze egymással a Montssori és a Konduktív Pedagógia?

- A gyógypedagógiai tanulmányaim során hallottam róla. Véleményem szerint jól beleilleszthető montessori szemléletbe a konduktív pedagógia, mert ott is nagyon fontos a gyermek önállóságra nevelése a motiváló környezet és a pedagógus példamutatása által.

- Köszönöm az interjút! 